Henning Bergenholtz \& Jan Engberg*

\title{
Tendenser inden for den nyere fagsprogsforskning $i$ Danmark
}

\section{Rammerne for dansk fagsprogsforskning}

I Danmark har man inden for de sidste årtier først og fremmest bedrevet fagsprogsforskning ved handelshøjskolerne og ved universitetscentrenes afdelinger for erhvervssprog. Dette kommer bl.a. til udtryk ved, at der ved Handelshøjskolen i København siden 1979 er kommet over 75 bind i serien ARK, primært om fagsproglige emner. Et andet tegn på denne tendens er det, at tidsskriftet Hermes (udgivet ved Handelshøjskolen i Århus) har en meget stor andel af fagsproglige artikler. Det karakteristiske ved disse institutioner er uddannelsen af tolke og oversættere, som ansættes i det private erhvervsliv. Fagsprogsforskningen har derfor i høj grad været rettet mod de krav, disse uddannelser stiller til sproglig viden (Kromann 1989, 127). Det var forskningens hovedopgave at støtte undervisningen på de erhvervssproglige uddannelser og derved sætte kandidaterne fra disse uddannelser i stand til at udføre deres opgaver på bedst mulige måde. En af konsekvenserne af disse betingelser er, at det langt overvejende flertal af fagsproglige forskningsprojekter beskæftiger sig med sproget inden for områderne $\emptyset$ konomi, teknik og jura. Disse fagsprog er relevante for danske virksomheder, da de er knyttet til virksomhedernes internationale arbejde, og det er følgelig dem, danske oversættere hyppigst konfronteres med i deres arbejde. Dermed er fagsprogsforskningen i Danmark stærkt praksisrelateret, og den praktiske oversættergerning har en væsentlig indflydelse på fagsprogsforskningens selvforståelse. Således besvarer Svendsen (1987) spørgsmålet om det legitime $i$ at bedrive fagsproglig forskning med en henvisning til erhvervslivet som aftager af de uddannede oversættere. Den stærke binding til praksis medfører, at det snarere er beskrivelse end bedømmelse af fagsprog, der står i fokus. Mao. har størsteparten af de fagsproglige arbejder ikke som mål at pleje og forandre sproget, men

\footnotetext{
Henning Bergenholtz \& Jan Engberg

Handelshфjskolen i Århus

Fuglesangs allé 4

8210 Aarhus V (DK)
} 
derimod at dokumentere den faktiske sprogbrug inden for et område. Af undtagelser fra denne regel kan nævnes arbejder, som beskæftiger sig med det offentlige sprog (Hansen 1986, Larsen 1987a, Henriksen 1991) og med sygeplejerskernes sprog (Larsen 1987b). Men det er snarere fagsproget som et redskab i faglige aktiviteter end fagsprog som gruppekendetegn, der studeres i Danmark. ${ }^{1}$

For det andet har den kendsgerning, at fagsprogsforskningen har været rettet mod oversætterens behov, medvirket til, at terminologilæren længe kunne bevare sin position som den primære videnskabsdisciplin inden for fagsprogsforskningen. Den fagsproglige oversættelsesundervisning må fokusere på kontrastive aspekter og dermed også på den encyklopædiske fagviden, som ligger til grund for fagtekster. For korrekt oversættelse af en fagtekst forudsætter tilsvarende viden. Og her er terminologilæren, der jo beskæftiger sig med relationen mellem begreber og benævnelser, en adækvat disciplin. Ved de erhvervssproglige institutioner er der også blevet bedrevet andre former for sprogforskning, men tendentielt har der været en skarp adskillelse mellem systemlingvistisk orienteret lingvistik og terminologisk orienteret fagsprogsforskning (Kromann 1988, 191; 1989, 131).

Som reaktion på dette forhold blev der oprettet i alt tre satsningsområder under Statens Humanistiske Forskningsråd, som skulle styrke fagsprogsforskningen i Danmark generelt. For det første drejer det sig om satsningsområdet "Fagsprog og fagkommunikation", der løb over perioden 1987-92 (se nærmere nedenfor og i denne artikels afsnit 3). Endvidere blev der inden for den samme periode oprettet et forskningsprofessorat ved Handelshøjskolen i Århus inden for fagleksikografi (se kap. 5). Og endelig blev der gennemført et storprojekt inden for området "Oversættelse af fagsproglige tekster" i perioden 1990-94 (se kap. 7). Hermed intensiveredes fors $\emptyset$ gene på at beskæftige sig med andet end terminologi inden for fagsprogsforskningen, uden dog at miste forskningens praksisrelevans af syne. Inden for projekterne har man fors $\emptyset \mathrm{gt}$ at anvende lingvistiske metoder på fagsprog, for derved at opnå endnu større viden om det specielle ved disse fagsprog (Kromann 1988, 193). Dette kræver, at viden fra flere områder føres sammen, for den lingvistiske specialviden må kombineres med den specifikke sagviden fra den enkelte fagområde. En sådan forskning har et meget heterogent

1 Skellet mellem disse synsvinkler uddybes af Larsen (1987a, 12-15). 
forskningsobjekt, og det er derfor nødvendigt at gå eklektisk til værks, når det skal beskrives (Mourier 1987, 5).

Et resultat af arbejdet inden for det førstnævnte satsningsområde har været opbygningen af en omfattende bibliografi for området fagsprog og fagkommunikation (Mikkelsen/Kromann 1988). Det drejer sig her om en maskinlæsbar bibliografi med ca. 10.000 registrerede værker, som omfatter artikler, bøger og tidsskrifter fra perioden 1970-88. Den omfattede litteratur beskæftiger sig med såvel fagintern som interfaglig og fagekstern kommunikation (Mikkelsen 1989, 133). Bibliografien udleveres til brug for videnskabelige formål uden beregning ved henvendelse til Tysk Institut, Handelshøjskolen i København. Den omfattende bibliografi har tjent som grundlag for yderligere to bibliografier: for det første en selektiv papirversion med ca. 1100 registrerede værker (Kromann/Mikkelsen 1988) og for det andet en permanent bibliografisk database ved Handelshøjskolen i København, som løbende ajourføres (Kromann 1991, 1995).

Som en konsekvens af de nævnte kendetegn ved fagsprogsforskningen i Danmark i dag har vi i denne fremstilling begrænset os til arbejder fra de seneste ca. 30 år og koncentreret os om de bidrag, der (også) har dansk som objektsprog. Den bredere beskæftigelse med fagsproglige emner falder sammen med, at fagsprog tages op som genstand for forskning ved de erhvervssproglige institutioner i løbet af tresserne. Før den tid fandtes der ganske vist også fagsproglige arbejder (som f.eks. Larsen 1895 om soldatersprog), men sådanne arbejder er nærmest sjældenheder. Endvidere har vi begrænset os til resultater fra de nævnte fagsprogsområder ( $\varnothing$ konomi, teknik og jura).

Hvad angår udvalget af forskningslitteratur inden for de undersøgte områder, som skulle behandles i denne fremstilling, må man sige, at det har været uproblematisk at vælge ud. Selv om man, som det vil fremgå af vort næste afsnit, også i Danmark har diskuteret og stadig diskuterer, hvordan man skal skelne mellem fagsprog og almensprog, er de fleste forfattere intuitivt ikke i tvivl om, at der findes fagsprog, og at fagsprog er en eller anden form for varietet $i$ forhold til den alment anvendte sprogbrug. I det følgende afsnit vil vi se på, hvilke opfattelser der har været repræsenteret i Danmark. 


\section{Fagsprog. Hvad er det?}

En skelnen mellem almensprog og fagsprog bliver af de fleste forskere anset for både nødvendig og mulig, men også for temmelig vanskelig (fx Sørensen 1983, 2). Skillelinien bliver dog ud fra de enkelte teoretiske grundsynspunkter draget på forskellig måde. Den ældre forskning det vil i fagsprogssammenhæng sige til op i 80erne - adskiller fagsprog og almensprog først og fremmest ud fra overvejelser om forskelle i ordforrådet: De ord, der ikke findes i almensproget, dialekter, gruppesprog o.l. tilhører fagsprog (fx Aalkjær (1970). Ud fra dette udgangspunkt kan man sige, at alle ord, der findes i almensproget også findes i fagsproget, men at der i fagsprog derudover findes en række særlige fagtermer. På denne måde bliver almensproget (AS) en del af fagsproget (FS):

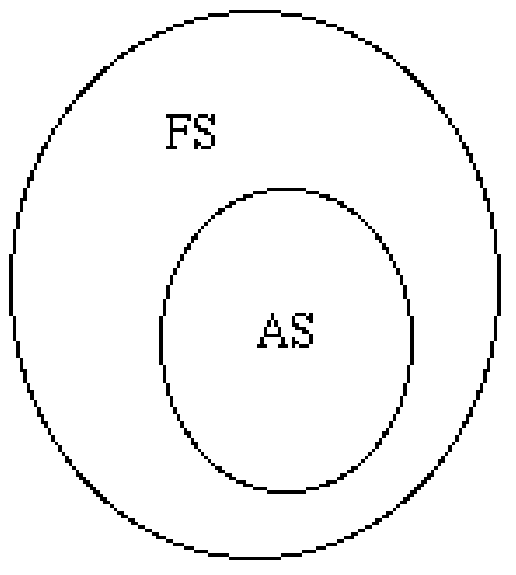

Denne opfattelse, som først og fremmest tager hensyn til ordforrådet, deles ikke af forskere, der tager udgangspunkt i de kommunikative sammenhæng, som hhv. almensprog og fagsprog indgår i. Fagsprog bliver brugt i kommunikation mellem fagfolk, mellem fagfolk og semifagfolk, og når fagfolk henvender sig til lægfolk. Der er ganske vist tale om forskellige former for fagsprog, men $\mathrm{i}$ alle tre tilfælde forudsættes der en fagviden hos tekstproducenten, som ikke foreligger hos lægfolk. Disse vil ganske vist indtil en vis grad kunne tale om de samme enkeltheder eller sammenhænge, som en fagmand gør, men ikke på en måde, som er forbundet med de samme handlinger og til dels ud fra en for- 
ståelse, som en fagmand vil betegne som ufuldstændig eller forkert (sml. Sørensen 1983). Fagsprog og almensprog bliver på denne måde ligestillede, men adskilte fænomener:
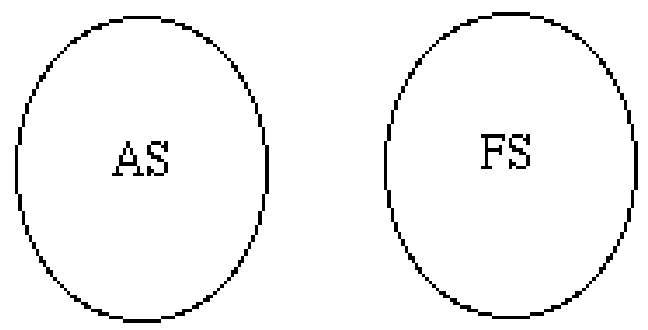

Et yderligere skridt $\mathrm{i}$ en tilordning af forskellige sprog til forskellige situationer fører til en afvisning af antagelsen af et almensprog. Alle situationer er på sin vis specielle og kræver både på tekstproducent- og recipientside særlige vidensforudsætninger. Man kan derfor anse enhver sprogvarietet som et eget fagsprog (Frandsen 1990). Dog kan man også gå ud fra forskellige grader af faglighed alt efter hvem der kommunikerer med hvem. I stedet for udtrykket fagsprog er den tilsvarende engelske term LSP, language for special purposes, på sin vis mere rammende: Enhver kommunikationssituation er speciel og kræver en mere eller mindre speciel viden (Frandsen 1990,15).

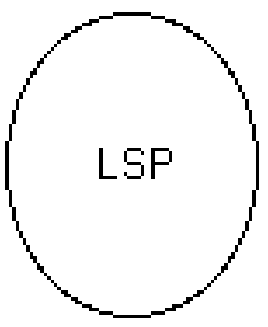

De fremførte argumenter, som fremføres mere udførligt i en lang række artikler af Kalverkämper, er på sin vis overbevisende. Men hvis de som i de nævnte tilfælde forbindes med en fuldstændig opgivelse af udtrykket almensprog, har det dog den kontraintuitive konsekvens, at hele forudsætningen for både store dele af modersmålsundervisningen og 
fremmedsprogsundervisningen, men også for de fleste grammatikker og mange af de mest solgte ordbøger ville falde væk (Mikkelsen 1990 og Bergenholtz 1992). Sproget, som disse grammatikker eller den fremmedsproglige undervisning vil formidle, kan ganske vist ikke føre til beherskelsen af en varietet, som uden indskrænkning og uden yderligere viden kan bruges i alle ikke-faglige kommunikationssituationer, men dog i en stor del. Dette sprog er forbundet med sproglige strukturer og elementer, som netop er kendetegnet ved, at de forstås alment af mange eller de fleste og også bliver brugt regelmæssigt. Et fagsprog derimod bliver kun brugt af en mindre del af et sprogs brugere. Det er derfor bedre, mener andre forskere, at gå ud fra en model, hvor der både antages et almensprog, et fagsprog og også en fællesmængde (FÆS), som indeholder elementer og strukturer i AS og FS (Spang-Hanssen 1983, Bergenholtz/Tarp 1994a,15). FÆS synes dog at have en anden status end AS og FS, idet der ikke angives eksempler på situationer, hvor FÆS bruges:

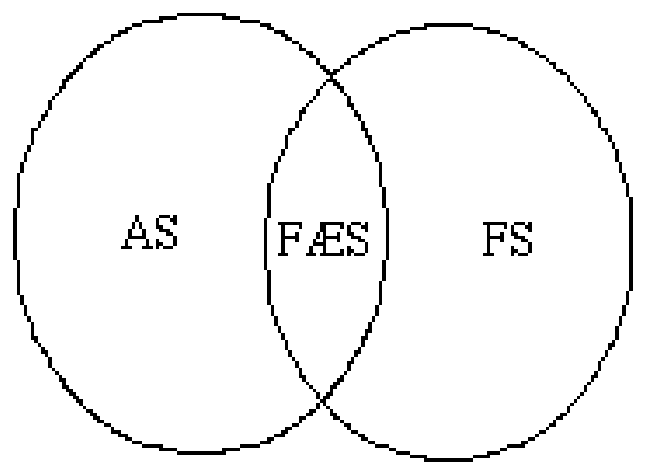

\section{Fagsproglige tekstkorpora}

Specielt i forbindelse med metodiske overvejelser inden for syntaksforskningen og den almensproglige semantiske forskning har lingvister ført lange diskussioner om valg af den relevante empiriske basis. Nogle forskere har anset lingvistens egen sprogkompetence for at udgøre den grundlæggende basis, andre har ytret tvivl om selvkonstruerede sætningers status i relation til konkrete kommunikationssituationer og har argumenteret for oprettelsen af store tekstsamlinger, tekstkorpora. 
En lignende strid har stort set ikke fundet sted inden for fagsprogsforskningen. En af grundene til denne forskel er uden tvivl, at lingvister normalt ikke vil være eksperter i det pågældende fag. Fagsprogslingvister vil således slet ikke kunne producere tekster eller brudstykker af tekster, som kan indgå i den empiriske basis. Alligevel var der indtil midten af 80erne kun sammenstillet ret få faglige, men en del almensproglige tekstkorpora, og tilsvarende forelå der kun få teoretiske overvejelser om fagtekstkorpora, jvf. oversigt i Bergenholtz/Pedersen 1993. Ud fra de foreliggende erfaringer med almensproglige tekstkorpora oprettede Statens Humanistiske Forskningsråd inden for rammerne af af det allerede nævnte satsningsområde "Fagsprog og fagkommunikation" et større tekstkorpusprojekt, som dels skulle udarbejde de nødvendige teoretiske koncepter, dels sammenstille en række tekstkorpora. I alt blev der oprettet seks korpora med hver 1. mio. tekstord: et dansk, et engelsk og et fransk korpus til temaet aftaleret (Dyrberg et al. 1988) og et dansk, et tysk og et spansk til genteknologi (Lauridsen/Riiber/ Søndergaard 1991). Der var i første omgang planlagt meget mindre korpora på omtrent 100.000 tekstord, som så skulle forsynes med grammatiske oplysninger. Denne del af planen blev dog opgivet, og et omfang som hos det amerikanske Brown-Corpus, det britiske LOB-Corpus og det tyske Limas-Korpus (sml. Schaeder 1979) og det danske DK-87 (Bergenholtz 1988) blev taget som forbillede.

De førstnævnte korpora består af præcis 2000 tekstord pr. korpustekst. De kan derfor ikke bruges optimalt ved tekstlingvistiske analyser, idet mange teksters begyndelse eller afslutning mangler. Der blev derfor som i DK-87, valgt en opbygning af de enkelte korpora, som omfattede hele tekster eller sådanne tekstdele, som tekstuelt udgør et hele. De enkelte korpustekster har derfor ikke alle samme omfang, i gennemsnit indeholder de 5000 tekstord (Dyrberg et al. 1988, 214).

Mere i tradition med erfaringerne fra de første amerikanske, engelske og tyske korpora er forsøget på at foretage et udvalg af tekster, som tager højde for frekvensen og vigtigheden af de enkelte fagområder og teksttyper. Ved oprettelsen af det aftaleretlige korpus blev denne vægtning foretaget på grundlag af udtalelser fra jurister (Dyrberg et al. 1988, 220 og 1991, 21-23). Det er ikke helt klart, om andre jurister end den lille gruppe, som blev anvendt som informanter, ikke ville have givet andre svar, men principielt er et samarbejde med fageksperter under oprettelse af et fagligt tekstkorpus fordelagtigt. Ud over det aftaleretlige 
korpus har Statens Humanistiske Forskningsråd støttet sammensætningen af et genteknologisk korpus. Her blev der taget udgangspunkt i fire kommunikationskonstellationer og til hver gruppe udvalgt tekster, hvis hyppighed angives i parentes (Lauridsen/Riiber/Søndergaard 1991, 129):

\section{Fagmand til fagmand (18\%) \\ 2. Fagmand til lagmand (38\%) \\ 3. Lagmand til fagmand (9\%) \\ 4. Lagmand til lagmand (35\%)}

Det genteknologiske tekstkorpus kaldes ikke et fagsprogskorpus, men et sagsprogskorpus, fordi grupperne 3 og 4 ikke indeholder tekster, som med rette kan kaldes fagtekster. De omhandler ganske vist de samme sagforhold, men ud fra forskellige vidensforudsætninger (Lauridsen/ Riiber/Søndergaard 1991, 129). Helt overbevisende er de fremførte argumenter dog ikke, idet det ikke er klart, om den der slet ikke har forstået grundlæggende genteknologiske processer også taler om det samme som en ekspert (Kaufmann 1993). Desuden kan det betvivles, om der virkelig foreligger genteknologiske tekster af fagfolk skrevet for fagfolk. Efter bedømmelse af en fagmand er alle tekster i gruppe 1 skrevet for lægfolk eller i genteknologisk sammenhæng for semifagfolk som fx medicinere (Stummann 1993).

Ud over de nævnte korpora er der udarbejdet tre andre fagkorpora. Det drejer sig dels om et engelsk genteknologisk korpus med 550.000 tekstord (Bergenholtz/Kaufmann 1991) og et engelsk og et dansk pumpeteknologisk korpus med hhv. 900.000 og 500.000 tekstord (Pedersen 1993).

De nævnte fagtekstkorpora har trods visse forskelle i konceptionerne det fælles kendetegn, at de så vidt som muligt er opbygget sådan, at to eller flere korpora tematisk og teksttypologisk svarer til hinanden. På denne måde kan de anvendes som empirisk basis for kontrastive arbejder af forskellig art, herunder også til bilingvale leksikografiske undersøgelser.

\section{Terminologi}

Terminologiforskningen ser det som sit hovedformål at undersøge vidensformidling i videste forstand. Dette formål bevirker, at elementerne 'genstand', 'begreb' og 'repræsentationsformer' sammen med re- 
lationerne mellem disse elementer er af største interesse for denne videnskabsgren (Picht 1993c, 37f.). På baggrund af forskningsgenstanden og dens bestanddele er der inden for den danske terminologiforskning opstået en række forskningsområder, som terminologiske arbejder kan tilskrives. Det drejer sig primært om det teoretiske område (Hvad er et begreb? Hvad er terminologiforskningens genstand?), om det metodiske område (Hvilke typer definitioner er mest velegnede, når man skal beskrive et terminologisk begrebssystem?) og om det præsentationstekniske område (Hvordan opbygger man en database eller vidensbank?).

I Danmark går det organiserede terminologiarbejde tilbage til starten af fyrrerne, hvor Det Danske Akademi for de Tekniske Videnskaber grundlagde en terminologicentral (Kristensen 1985, 4; Spang-Hanssen 1979, 12ff.) Denne første fase af terminologisk arbejde varede frem til 1960, hvorefter der i tresserne ganske vist blev lavet terminologiarbejde, men uden en national koordinering. Mulighederne for forskningsarbejde med bredere sigte blev først for alvor øget, da Handelshøjskolen i København tog terminologien op som undervisningsfag og forskningsområde og oprettede en terminologiafdeling ved Handelshøjskolen i 1974 (Picht 1985a). Et af resultaterne af denne satsning var opbygningen af en national terminologisk database, DANTERM (Engel/ Nistrup Madsen 1985; Engel 1979b; Danterm Project Group 1979). Formålet med basen var for det første, at den skulle være et central registreringsinstans for terminologiarbejdet ved Handelshøjskolen og ved andre institutioner i Danmark. For det andet skulle DANTERM fungere som serviceorgan for virksomheder med sprogproblemer. Og for det tredje skulle det, at man fik en central koordinering, gøre det muligt at anvende computere (hvilket på dette tidspunkt krævede mange ressourcer). For at opfylde disse formål opbyggede man en begrebsorienteret database, hvor man så vidt muligt registrerede termer fra forskellige sprog under de samme definitioner (Nistrup Madsen 1985, 459). I denne forbindelse viste det sig som et problem, at man i databasen $\emptyset$ nskede at registrere termer fra såvel kulturbundne som kulturneutrale fag. Kun ved kulturneutrale fagområder er multilingual tilskrivning af termer uden videre mulig. Som en konsekvens af disse problemer arbejder man derfor i nogle tilfælde i stedet med terminologier relateret til bestemte sprogpar (Danterm Project Group 1979). Endvidere førte også de manglende finansielle midler, som DANTERM-styregruppen kunne 
have anvendt til at styre, på hvilke områder der skulle udarbejdes terminologier, til en meget stor spredning i de udarbejdede terminologier, hvilket til en vis grad har nedsat den praktiske nytte af databasen som grundlag for en rådgivningstjeneste.

Det praktiske terminologiarbejde på DANTERM og på andre terminologiprojekter gav anledning til en række arbejder, der beskæftiger sig med terminologiens metoder og med uddannelsen af terminologer. I overensstemmelse med terminologiens grundlæggende opfattelse er DANTERM onomasiologisk opbygget. I centrum står begrebet og dets definition. Ved 'begreb' forstås en tankeenhed, der er uafhængig af enkeltsprog, og som dannes ved abstraktion på grundlag af en genstands karakteristiske træk (individualbegreb) eller på grundlag af en klasse af genstandes karakteristiske træk (almenbegreb) (Picht 1985b, 51). Begrebet anses som værende uafhængig af den benævnelse, hvormed man kan kommunikere om begrebet (Arntz/Picht 1989).

Denne kendsgerning betyder, at det får betydning, hvilken type definition man vælger som grundlag. Hvilke typer af definitioner egner sig så bedst til terminologiformål? $\mathrm{Og}$ skal man udelukkende arbejde med autentiske definitioner fra relevante fagbøger? Ifølge Frandsen (1982, 26-34) er de mest velegnede definitioner såkaldte indholds-, omfangsog relationsdefinitioner. Disse stiller de informationer om et begreb til rådighed, som er nødvendige for at kunne indplacere begrebet $\mathrm{i}$ en systematik (genus proximum, differentia specifica og relationer til andre begreber). Kan man finde autentiske definitioner af denne type, bør disse foretrækkes. Men findes sådanne ikke, er det terminologens opgave i rollen som sproglig rådgiver for en gruppe af fageksperter at hjælpe med at opstille definitioner, som overholder generelle kriterier for gode definitioner (Frandsen 1982, 44-54; 136-137; Frandsen 1979a). Ved fag, der som f.eks. biblioteksvæsenet mangler en fast og anerkendt struktur, foretrækker Spang-Hanssen (1984) derimod at anvende definitioner og ordforklaringer, der er mindre formaliserede end dem, som Frandsen beskriver.

En væsentlig kritik mod terminologilærens grundopfattelser (begrebet som udgangspunkt for terminologiarbejde, begrebets uafhængighed af benævnelsen) er blevet formuleret af Hauschildt (1989). Kritikken baserer han på, at grundopfattelserne forudsætter en skelnen mellem begreb og benævnelse, som ikke er holdbar (Hauschildt 1989, 107). Derved opstår ontologiske problemer, som ikke kan løses inden 
for terminologilæren (Hauschildt 1989, 110). I stedet går Hauschildt ind for en opfattelse, som tager sit udgangspunkt i en gensidig forudsætningsrelation mellem begreb og benævnelse, og som tager udgangspunkt i det, der er til stede og følgelig er lettest at bestemme, nemlig i benævnelsen. Han angriber dermed ikke begrebets stilling som væsentlig bestanddel af en betegnelseshelhed, men derimod antagelsen af, at begrebet har første rang i forhold til benævnelsen (jvf. også Frandsen 1979b).

Et andet punkt, der har haft væsentlig betydning i Danmark, er spørgsmålet om terminologilærens rolle i forbindelse med uddannelsen af oversættere o.lign. Det har vist sig, at en lang række af eksperter fra forskellige discipliner (f.eks. lingvister, oversættere, juridiske og tekniske eksperter osv.) har været interesseret i terminologisk arbejde, men at de normalt alle mangler dele af den nødvendige viden (fra lingvistikken, filosofien, klassifikationen, oversættelsesvidenskaben og videnskabsteorien, Picht 1985g, 682; 685). For at afhjælpe disse mangler, udnævnte man udviklingen af et undervisningsforl $\varnothing \mathrm{b}$ for terminologer til en af de væsentligste opgaver for terminologiafdelingen ved Handelshøjskolen i København (Picht 1979, 28; Picht 1985g, 688). Ligeledes er det blevet fremhævet, hvor ønskværdigt det er, at fagfolk fra de videnskaber, terminologierne opstilles for, gennem suppleringskurser på tekniske skoler o.lign. sensibiliseres for sprogproblemernes betydning. Dette sidste ønske er dog kun i begrænset omfang blevet opfyldt, da terminologiundervisningen indtil nu næppe er kommet ud over at være en aktivitet på handelshøjskolerne, hvor terminologikurser udgør en integreret del af sproguddannelsen.

Hvad endelig angår spørgsmålet om det teoretiske grundlag for terminologiforskningen, var udgangspunktet som sagt Wüsters terminologilære med dens fokusering på begrebet, dets benævnelse og relationerne til andre begreber inden for et begrebssystem (Picht 1985c). Da Wüster imidlertid udformede sin lære om standardiseringen af teknisk terminologi, og da terminologiarbejdet i Danmark for det første også beskæftigede sig med ikke-tekniske fagområder og for det andet ofte ikke har et normativt, men snarere et deskriptivt formål, var det nødvendigt at modificere Wüsters terminologilære (Picht 1985f, 42). Man kan se modifikationen i den følgende beskrivelse af terminologilærens forskningsgenstand: 
"Terminologilarens forskningsgenstand er udforskning, analyse og afprovning af de principper og adcekvate metoder, der kan finde anvendelse ved indsamling, analyse, systematisereing og fremstilling af alle, nogle eller enkelte fagområders specifikke sprogmidler under hensyntagen til disse fagområders sarlige, terminologisk relevante karakteristika." (Picht 1985f, 43.)

Modifikationen består altså bl.a. i, at terminologiens genstandsområde er blevet udvidet væsentligt. Ikke kun begrebssystemerne og de tilsvarende benævnelser er af interesse, men "de specifikke sproglige midler" der anvendes inden for et fagområde. Vi ser arbejder som Picht (1985e) om fagsproglig fraseologi generelt og Picht (1983) og (1988) om verbers terminologiske status som eksempler på og resultater af denne udvikling. Med disse arbejder bevæger terminologien sig, som også bemærket af Kewley-Draskau (1994, 106f.) i retning af lingvistiske beskrivelsesområder, der også kan bearbejdes uden at anvende terminologiens instrumentarium. For såvel til temaet fraseologi i $\emptyset$ konomiske tekster (Faber 1983) og til faste ordforbindelser i juridiske tekster (Kjær 1990) findes der arbejder, som gennemføres uden henvisning til terminologilæren. Også Annelise Grinsteds licentiatarbejde (Grinsted 1991) anser vi for at være en sådan videreudvikling af terminologiforskningen. I dette arbejde unders $\emptyset$ ger forfatteren, hvilke betingelser terminologiarbejde udføres under i virksomhederne. Der lægges specielt vægt på, hvordan terminologiarbejde kan markedsføres som værktøj i forbindelse med moderne metoder inden for virksomhedsstyring, og terminologilæren tilnærmes dermed til ledelsesforskningen. Endelig udgør området vidensrepræsentation, som i de seneste år er blevet optaget i terminologiforskningen (f.eks. Picht 1993a, 1993b; Toft 1993b), en yderligere udvidelse af genstandsfeltet. Med dette område inddrages kognitionspsykologien i terminologiforskningen. Så længe terminologilæren i denne forbindelse ses som en videnskab med en central placering i fagsprogsforskningen, som gennem samarbejde med andre discipliner i højere grad end tidligere kan beskrive den fælles forskningsgenstand (Kromann/Thomsen 1989; Picht 1993c), kan man kun byde en sådan udvikling velkommen. Men den oven for anførte definition viser ikke med sikkerhed, at terminologiforskningen $\emptyset$ nsker at arbejde med en sådan arbejdsdeling og gensidig afgrænsning. Og anvendes definitionen som beskrivelse af terminologilærens objekt, er vi blot endnu engang tilbage ved at sætte lighedstegn 
mellem terminologi og fagsprogsforskning, et lighedstegn, som man i Danmark har forsøgt at ophæve inden for de seneste 10 år.

\section{Fagleksikografi}

Der skelnes i de fleste arbejder skarpt mellem terminologi og leksikografi. Ofte opfattes terminologi som den systematiske indsamling af fagtermer, mens der ved leksikografi forstås udarbejdelsen af ordbøger og leksika (Andersen 1979, 7). Leksikografer og terminologer har dog en anden selvforståelse af deres respektive fag. Leksikografer anser udarbejdelsen af ordbøger og leksika som den ene side af deres fag, som forholder sig komplementært til den anden side, til metaleksikografien eller den teoretiske leksikografi. Både den teoretiske og den praktiske leksikografi beskæftiger sig med fagsprog, dvs. med fagleksikografi (Bergenholtz/Tarp 1994a). Heller ikke terminologer vil være enige i den noget indskrænkede forståelse af de to områder, men har igen en anden inddeling. Efter 1975 er det blevet almindeligt at antage et terminologisk delområde, som kaldes terminografi. I overensstemmelse med ISO 1087 skal dette udtryk erstatte "terminological lexicography” og "special lexicography” (Picht 1985d, 353). Adskillelsen mellem terminologi hhv. terminografi og leksikografi bliver begrundet med en række argumenter, som påviser en forskel:

(a) I modsætning til leksikografien har terminologien udelukkende fagsprog som objekt (Picht 1985d, 353 og Grinsted/Toft 1994, 71).

(b) I terminologien arbejdes der kun med fageksperter som informanter, hvorimod man i leksikografien kan bruge enhver native speaker (Frandsen 1979b, 24f).

(c) I terminologien arbejdes der onomasiologisk, mens leksikografien arbejder semasiologisk (Engel 1979a og Maidahl Christiansen/Duvå/ Laursen 1994, 276).

(d) Terminologien er primært præskriptiv, mens leksikografien primært har et deskriptivt sigte (Engel 1979a og Maidahl Christiansen/Duvå/ Laursen 1994, 272).

(e) I modsætning til leksikografien foretrækker man i terminologien en systematisk makrostruktur fremfor en alfabetisk makrostruktur (Picht 1985d, 366ff).

Leksikografer afviser disse argumenter, de gælder for dele af leksikografien, men ikke som en generel beskrivelse, heller ikke af den teore- 
tiske eller den praktiske fagleksikografi. Punkterne (a), (b) og (d) ville kun være rigtige, hvis man som forsøgt i ISO 1087 gik med til at afskaffe udtrykket fagleksikografi og udelukkende forstod leksikografi som sprogleksikografi. Dette svarer dog ikke til fagleksikografers selvforståelse, der anser terminografi og fagleksikografi for stort set synonyme udtryk (Bergenholtz 1994). Det er ganske vist rigtigt, at man i fagsprogssammenhæng har et større behov for præskription og en normerende dannelse af nye termer end det er tilfældet i almensproget, men det gælder både for terminografisk og fagleksikografisk arbejde. Det adskillende argument (c) kan ligeledes ikke holde, da også fagleksikografer arbejder fagsystematisk (Pedersen 1994a og 1994b), men i praksis tager udgangspunkt i termen, dvs. i leksikografisk terminologi i det sproglige tegns udtryksside (Frandsen 1979b, 10f og 18ff). Endelig beskriver argumentet (e) uden tvivl en vis præference, både i teori og praksis. Det er dog ingen nødvendig modsætning, da begge makrostrukturer har sine fordele (Nielsen 1994).

Den danske fagsprogsforskning er præget af en stærk fagleksikografisk interesse. Det ses bl.a. også i dannelsen af to nye leksikografiske institutter, i leksikografi og datalingvistik på Handelshøjskolen i Århus (1994) og i leksikografi på Handelshøjskole Syd, Afdelingen i Varde (1994). Ved det førstnævnte institut er der desuden oprettet et professorat i bilingval fagleksikografi. Samtidig har fagleksikografi spillet en central rolle i gennemførelse af satsningsprojektet "Oversættelse af fagsproglige tekster". I denne forbindelse kan også nævnes samarbejdet med tilsvarende forskningsgrupper i Siegen (Schaeder/Bergenholtz 1994) og i Havanna (Bergenholtz/Kaufmann/Tarp 1994). Denne forskning har ført til følgende foreløbige metaleksikografiske teser:

1. Overvejelser om ordbogsfunktioner må danne udgangspunkt for enhver fagleksikografisk teori og praksis (Tarp 1994a). De konkrete brugerbehov er blevet undersøgt på grundlag af ordbogsprotokoller, som blev udarbejdet under oversættelse af fagtekster (Duvå/Laursen/Maidahl 1992, Maidahl 1992, Balsgart 1992, Møller 1992, Nielsen 1994). Analysen af disse protokoller har bl.a. ført til kravet om at indarbejde semantiske hhv. encyklopædiske angivelser i fagordbøger. Uden sådanne angivelser vil ordbogsbrugeren i en række tilfælde ikke kunne få tilstrækkelig hjælp ved oversættelsesproblemer og ved tekstreceptionsproblemer. Det gælder 
særligt for kulturbundne fag som fx økonomi og jura, men indtil en vis grad også for kulturneutrale fag som fx tekniske og naturvidenskabelige fag.

2. De fleste foreliggende fagordbøger er flerfagsordbøger, hvor det ofte drejer sig om mere end 100 fag. Sådanne ordbøger vil i praksis hverken kunne give et tilstrækkeligt bredt udsnit af de enkelte fag eller en virkelig nøjagtig beskrivelse deraf. I stedet foreslås udarbejdelse af konceptioner til polyfunktionale enkeltfagsordbøger (Tarp 1994a).

3. Udarbejdelsen af en fagsystematik udgør en central del af forarbejdet til en fagordbog. Der kan skelnes mellem tre former: ekstern og intern fagsystematik og termsystematik. Tilsammen udgør disse systematikker en væsentlig del af grundlaget for samtlige selektionsprocesser i ordbogsarbejdet og for udarbejdelsen af faglige forklaringer hhv. definitioner (Pedersen 1994b).

4. I tillæg til de traditionelle ordbogskomponenter som forord, brugervejledning og ordliste er der udarbejdet en konception til specielle oversigter over en ordbogs fag. Denne oversigt skal dels være basis for henvisninger fra de enkelte artikler til større systematiske sammenhænge, dels kunne bruges som en indføring i faget (Tarp 1994b). Denne komponent er allerede indgået i konkrete ordbøger (Henriksen 1992, Kaufmann/Bergenholtz 1992, Gubba 1993, Bergenholtz 1995).

5. I stedet for den form for bagsidetekst, de fleste ordbøger allerede bringer i form af en blanding af information og reklame, bør der anføres en varedeklaration, som skal give brugeren nøjagtige oplysninger om ordbogens grundelementer og omfang (Møller 1994).

6. Der foreligger forslag til dels helt nye, dels forbedrede koncepter til indarbejdelse af grammatiske informationer, informationer om ordforbindelser og om sætningseksempler (Bergenholtz/Tarp 1994b med yderligere litteraturhenvisninger).

\section{Grammatiske og tekstlingvistiske arbejder}

Den del af den danske fagsprogsforskning, der er behandlet indtil nu, har været koncentreret omkring fagtermen, jvf. vores indledning. Udover dette område har dog også områderne grammatik, stilistik og prag- 
matisk tekstlingvistik været involveret i dansk fagsprogsforskning. Som det vil kunne ses af den følgende fremstilling, beskæftiger mange af disse arbejder sig med det juridiske fagsprog, selv om der også her forekommer arbejder inden for andre fagsprog. Dette skyldes sandsynligvis, at de kendetegn ved juridisk sprog, som umiddelbart falder i øjnene, ikke i så høj grad ligger i ordforrådet, men snarere i sætningsog tekstopbygningen. Følgelig er det her mere oplagt at lave grammatiske og tekstlingvistiske undersøgelser, end det er tilfældet ved tekniske fagtekster (selv om det naturligvis også kan være relevant ved den sidstnævnte gruppe af tekster).

Generelt tages der ved grammatiske arbejder udgangspunkt i tekstgenren. Det undersøges, hvilke dele af sprogsystemet der anvendes i tekster fra en bestemt genre. Dermed støtter man i det mindste implicit den opfattelse, at fagsprog primært adskiller sig fra det almindeligt anvendte hverdagssprog ved at have en anden hyppighed i forekomsten af bestemte kendetegn, selv om man inden for grammatikkens område kan finde konstruktioner, der er specielle for et bestemt fagsprog (jvf. Sørensen 1994, 20; Nordborg Nielsen 1994a, 83). Et typisk eksempel på et sådant arbejde er undersøgelse af tempus- og modusbrugen i tyske og danske landsretsdomme (Harboe/Poulsen 1983). Forfatterne undersøger, hvordan tempus- og modusbrugen ser ud i denne tekstgenre, og hvordan man kan forklare den. Dette sker på grundlag af en beskrivelse af den generelle forskel mellem fortællende og rapporterende tempora og på grundlag af de generelle grammatiske regulariteter ved gengivelse af indirekte tale på de to sprog. Et andet eksempel er en tredelt analyse af danske, tyske, engelske og franske love og lovparagraffer om skilsmisse (Hansen/Lundquist/Rasmussen 1978). Analyserne angår syntaksen og dennes relation til de repræsenterede forhold (Rasmussen 1978), semantiske kasus og deres relation til det repræsenterede univers (Lundquist 1978) og relationer mellem afsender og tekst og mellem afsender og modtager, som er umiddelbart synlige i teksten (Hansen 1978). Med hele analysen tilstræbes en bred registrering af genrekendetegn inden for forskellige sprog, som tænkes anvendt ved planlægningen af undervisningen i oversættelse. Målet med studierne er dermed det samme som hos Harboe/Poulsen (1983), nemlig at registrere og om muligt forklare sproglige karakteristika ved en genre. I samme retning går også Engberg (1992a), som beskriver konventionaliserede markeringer af referat i landsretsdomme, Hare Hansen (1992), som 
undersøger sproget i brochurer om landbrugsmaskiner, og Lauridsen (1992), som undersøger modalverber og deres betydning i juridisk sprog kontrastivt.

En gruppe af grammatisk-tekstlingvistiske arbejder beskæftiger sig med fagsproget ud fra et stilistisk og forståelighedsmæssigt perspektiv. Især juristen W.E. von Eyben har beskrevet stilistiske særtræk ved det danske retssprog ud fra denne synsvinkel (f.eks. Eyben 1989), und han har haft en meget væsentlig indflydelse på udarbejdelsen af en sproglig vejledning fra Justitsministeriet (Justitsministeriet 1969). Effekten af denne vejledning er undersøgt i flere arbejder og anses for at have været betydelig (jvf. Karker 1982; Hamburger 1988). Andre eksempler på undersøgelser af stiltræk ved fagsprog angår domssproget (Blume 1985, Spleth 1987), sproget i forsikringsbetingelser (Normann Jørgensen 1984) såvel som det offentlige sprog, der anvendes i cirkulærer, forordninger og taler inden for EF (Karker 1980, 1993). Også Aalkjær (1970) og Riis (1981), som beskriver medicinsk fagsprog, og Munck (1994), som behandler dansk teknisk sprogbrug generelt, hører til denne gruppe. Ved alle disse arbejder går man ud fra, at en faglig og ikke nødvendigvis umiddelbart forståelig sprogbrug er nødvendig for kommunikationen inden for et fag. Men fagmanden bør for det første altid være opmærksom på, om hans fagsprog virkelig lever op til fagets krav. Og for det andet bør han kun anvende det i sammenhænge, hvor der virkelig er behov for præcis og entydig kommunikation. Her må man være specielt agtpågivende, når der er tale om kommunikation med lægfolk (jvf. f.eks. Hamburger 1982; jvf. også afsn. 8).

Udover disse syntaktisk og stilistisk orienterede arbejder findes der endelig en gruppe, der primært beskæftiger sig med fagsproglige tekster ud fra en handlingsteoretisk synsvinkel. Med udgangspunkt i Searles sproghandlingsteori analyserer f.eks. Schack (1990) Aftaleloven og bestemmer herved lovteksten som en opstilling af gyldighedsbetingelser for kontrakter. Med samme udgangspunkt sammenligner Hjort-Pedersen (1994) konventionelt anvendte sætninger i danske og engelske testamenter og anvender i denne forbindelse sproghandlinger som tertium comparationis. I forlængelse af den østtyske teori om funktional-kommunikativ sprogbeskrivelse beskriver Engberg (1992b) die sproglige delhandlinger, der forekommer i landsretsdomme. Denne gruppe af arbejder har til fælles, at de beskæftiger sig med skriftlige tekster, hvorved arbejder som Engberg (1992b) i højere grad er rettet 
mod beskrivelse af sproglige kendetegn end arbejder af den type, som de to andre hører til. Inden for de pragmatiske arbejder findes der endelig en ganske stor gruppe af arbejder, som ud fra en diskursanalytisk synsvinkel undersøger mundtlige forhandlinger (f.eks. List/ Wagner (1992), Bülow Møller (1991) og Firth (1991)).

Den danske fagsprogsforskning består altså af ligeså bred en vifte af undergrupper som den lingvistik, den er udgået fra. Dermed har den gennemløbet udviklingen fra fokussering på fagordet til beskæftigelse med hele fagtekster, som den kendes fra den $\emptyset$ vrige europæiske fagsprogsforskning (jvf. Hoffmann 1988). I hvert fald i Danmark har denne udvikling i høj grad været betinget af, at fagsprogsforskningen har været udført med oversættelse og oversættelsesdidaktik for $\emptyset$ je. Dermed blev det uomgængeligt at udvide genstandsfeltet, så at man nu kan tale om en egentlig fagsprogslingvistik. For denne lingvistik spiller relationerne til praxis en stor rolle - $\mathrm{i}$ ordets egentlige forstand er der tale om anvendt lingvistik.

\section{Oversættelse}

Oversættelse har været en grundlæggende problemstilling for den fagsproglige leksikografi, terminologi og tekstlingvistik, som indtil nu er blevet præsenteret i dette arbejde. Denne disciplins betydning er også synlig i Mikkelsen/Kromanns (1988) bibliografi. Opbygningen af et storprojekt "Oversættelse af fagsproglige tekster" (OFT-projektet), som blev gennemført som et kooperationsprojekt med deltagelse af 25 forskere fra fem danske højere læreanstalter, lå dermed i følgerigtig forlængelse af SHF-satsningsområdet "Fagsprog og fagkommunikation".

Også i forbindelse med oversættelse er det relevant at skelne mellem kulturbundne og kulturneutrale fagsprog. Et kulturbundet fagsprog er karakteriseret ved, at alle tekster, som er formuleret inden for dette fagsprog, potentielt kun dækker et bestemt kulturelt eller nationalt område og ikke gengiver forhold, der gælder uden for denne kultur. Dette er specielt synligt ved det juridiske og økonomiske fagsprog. Ved de kulturneutrale fagsprog som f.eks. de fleste tekniske fagsprog er denne begrænsning ikke til stede. Men også ved disse fagsprog kan forståelsen af bestemte deltekster forudsætte kendskab til sammenhænge, der er specifikke for et land og for en kultur, specielt ved inddragelse af juridiske elementer. I sådanne tilfælde er det væsentlige spørgsmål, hvordan sådanne deltekster skal oversættes. Hvis der f.eks. forekommer 
en frase som \$7-godkendt komponent, kan man vælge mellem tre oversættelsesstrategier (Sørensen 1992, 140):

1. Der vælges en ordret oversættelse, bl.a. med anvendelse af elementet $\$ 7$ i oversættelsen.

2. Der tilføjes information om den lov, som den nævnte $\$ 7$ forekommer i - hvilket igen kunne få læseren til at undersøge den relevante lov.

3. Der søges en oversættelse, som henviser til den tilsvarende lov i målsprogskulturen. Dvs. at man vælger at gengive udgangsudtrykket med et andet paragrafnummer fra en anden lov eller ikke at henvise til en lov, men til en anden form for bekendtgørelse.

Når det som i det anførte eksempel drejer sig om anvendelsen af et produkt, bør den tredje løsning foretrækkes. Iflg. Nordborg Nielsen (1992, 57f.) vil dette regelmæssigt være tilfældet i tekniske tekster. Men hvis det drejer sig om at beskrive sammenhænge i udgangsteksten eller om at beskrive dennes baggrund, kan det være mere fordelagtigt at vælge den anden løsning. Den første strategi kan derimod i begge tilfælde føre til misforståelser eller i det mindste til forståelsesvanskeligheder. Madsen (1994), som også beskæftiger sig med oversættelse af kulturbundne juridiske udtryk uden ækvivalent i målsproget, ser i denne forbindelse en adækvat løsning i, at man (jvf. løsning nr. 2) giver information om formålet med den juridiske handling, der udtrykkes ved kildesprogstermen (Madsen 1994, 138).

For at kunne give sådanne fagspecifikke tillægsinformationer må oversætteren råde over indgående kendskab til faget (Braasch et al. 1994, 99-104; Jakobsen 1992a, 4f.; 1994b, 41; Nordborg Nielsen 1994b, 1994c; Sørensen 1994; Krogh-Hansen 1994, 114). Endvidere må den ideelle oversætter selvfølgelig også kunne beherske det pågældende sprog og råde over viden om dettes regelmæssigheder (Villemoes 1983). Dette kan imidlertid ikke - eller i hvert fald ikke udelukkende - betyde, at oversætterens kompetence angår det almene sprog. Dannelsen af komposita og ligeledes anvendelsen af kollokationer er specifik for alle fagsprog, i nogle tilfælde mere og i andre mindre, og allerede dette forhold gør en speciel kompetence nødvendig, hvis man skal løse fagsproglige oversættelsesopgaver på en adækvat måde (Bergenholtz/Tarp 1994b; Boje/Braasch 1992; Faber 1983; Jakobsen 1992b, 1994b, 42; Thomsen 1993). 


\section{Perspektiver}

I avisers "sproghjørne", men også i mange sprogvidenskabelige bidrag kritiseres brugen af fagsprog, specielt fagtermer, fordi de forringer muligheden for en direkte forståelse. En sådan kritik er også baggrunden for det provokative krav: "Ned med fagsproget" (titlen på Larsen 1987a). Der gives to teksteksempler, som skal repræsentere den dårlige sproglige kvalitet. Det ene eksempel er på flere måder særligt instruktivt. Det drejer sig om et brev fra de sociale myndigheder til ældre medborgere, hvorfra her indledningen citeres:

"I anledning af De den 7/8-86 er visiteret til plejehjemmet "Kildevang" skal det herved meddeles, at pensionen for oktober måned 1986 ikke udbetales kontant, men anvendes som delvis daekning af opholdet på hjemmet."

Dette forvaltningssprog, mener Larsen (1987a), forstår de ældre medborgere ikke eller ikke helt, og derudover er det en meget upersonlig og uvenlig stil. Han foreslår derfor et andet brev med principielt samme indhold:

"Tillykke med, at De den 7/8-86 har fået plads på plejehjemmet "Kildevang”. Vi håber, De må få gavn og glade af opholdet. Men en plejehjemsplads koster jo penge, og som De sikkert har fået at vide tidligere, vil Deres pension for fremtiden skulle gå til dakning af Deres ophold på hjemmet. De vil derfor ikke få udbetalt pensionen for oktober måned kontant, men De vil få "lommepenge" til Deres personlige forn $\phi d e n h e d e r$. Det drejer sig for tiden om 575 kr. pr. måned."

Imod en sådan "forbedring” argumenterer Grøn (1988). Forslaget er ingen forbedring, men en forringelse med en noget nedsættende tone, som ifølge en lille rundspørge blandt ældre medborgere blev opfattet som fornærmende. Det gælder i særlig grad for udtrykket "lommepenge". I virkeligheden drejer det sig om en emotionelt ikke helt uproblematisk sammenhæng, hvor man efter Grøns mening snarere bør bruge en objektiverende upersonlig stil, svarende til det oprindelige brev.

Vi har her et eksempel på, at en kritik af fagsprogs ordvalg og stil på sin vis kan være berettiget, men at "fagsprogskirurgen" (Grøn 1988) nogle gange opererer, hvor det ikke er nødvendigt. I sin stræben efter forbedring af forvaltningssproget overser Harms Larsen, at dette sprogs stil og ordvalg på mange punkter er hensigtsmæssig. Det betyder ikke, at sprogkritiske bidrag i alle tilfælde vil være overflødige, de kan både være nyttige og læseværdige (Hansen 1986). Men tyngdepunktet i 
dansk fagsprogsforskning ligger ikke her. Som nævnt i indledningen forudsættes, at de foreliggende fagsprogstypiske tekster stort set svarer til de fagkommunikative opgaver. En sådan deskriptiv fagsprogsforskning, som den bedrives af flertallet af danske fagsprogsforskere, forudsætter derfor på samme måde som fagsproglig oversættelse primært kendskab til det unders $\emptyset$ gte faglige handlingsfelt og de faglige genstande og sagforhold, der behandles herindenfor. Genuin fagsprogsforskning af denne type kan ikke bedrives uden en sådan viden.

\section{Litteratur}

Aalkjær V. (1970): Doktorlatin. Sygdomsbekcempelsens og Sundhedsarbejdets Fagsprog. 3. udg. København.

Andersen, Eyvind Andersen (1979): Ordbøger. Oversattelse. Terminologi. Lyngby.

ARK 65 = Oversættelse af fagsproglige tekster. Indlæg fra Sandbjergkonferencen den 21.-22. november 1991. København 1992.

Arntz, Reiner/Picht, Heribert (1989): Einführung in die Terminologiearbeit. Studien zu Sprache und Technik. Hildesheim/Zürich/New York: Olms.

Balsgart, Karin Balsgart (1992): En brugerunders $\emptyset$ gelse og dens problemer. Ordbogsbrug ved oversættelse af engelsk teknologisk tekst. In: ARK 65, 245-282.

Bergenholtz, Henning (1988): DK87: Et korpus med dansk almensprog. In: Hermes 1, 229-237.

Bergenholtz, Henning (1992): Almensproglige informationer i fagordbøger. In: Nordiske studier i leksikografi. Rapport fra Konferanse om leksikografi i Norden 28.-31. mai 1991. Red. av Ruth Vatvedt Fjeld. Oslo 244-259.

Bergenholtz, Henning (1994): Zehn Thesen zur Fachlexikographie. In: Schaeder/Bergenholtz, 43-56.

Bergenholtz, H./Jakobsen, A.L./Maegaard, B./Mørk, H./Skyum-Nielsen, P. (eds) (1994): Translating LSP Texts. Conference papers for the OFT Symposium 11-12 April 1994. København.

Bergenholtz, Henning/Kaufmann, Uwe (eds.) (1991): Gene Technology Corpus. Århus.

Bergenholtz, Hennning/Kaufmann, Uwe/Tarp, Sven (1994): Vore mænd i Havanna: Udarbejdelse af konception til en spansk-engelsk genteknologisk ordbog. In: Hermes 13, 291-304.

Bergenholtz, Henning/Pedersen. Jette (1993): Tekstkorpora til brug ved udarbejdelse af fagordbøger. In: Engel, 37-55.

Bergenholtz, Henning/Tarp, Sven med bidrag af G.Duvå/O.Norling-Christensen/A.L.Laursen/H.K.Mikkelsen/S.Nielsen/J.Pedersen (1994): Manual i fagleksikografi. Udarbejdelse af fagordbøger-problemer og løsningsforslag. Herning . (= 1994a) 


\section{0}

Bergenholtz, Henning/Tarp, Sven (1994): Mehrworttermini und Kollokationen in Fachwörterbüchern. In: Schaeder/Bergenholtz, 385-419. (= 1994b)

Bergenholtz, Inger (1995): Musikleksikon. København: Politiken.

Blume, Peter (1985): Dommens sprog. In: Ugeskrift for Retsvaesen 42, 313-320.

Boje, Frede/Braasch, Anna (1992): Hvad får man skudt i skoene? Flerordsenheder i aktive ordbøger for mennesker og maskiner. In: Nordiske studier i leksikografi. Rapport fra Konferanse om leksikografi i Norden 28.-31. mai 1991. Red. av Ruth Vatvedt Fjeld. Oslo, 483-500.

Braasch,A./Maegaard, B./Nordborg Nielsen, J./Neville, A. (1994): Domain Restricted Translation. In: Bergenholtz et al., 91-126.

Bülow-Møller, Anne Marie (1991): Fællesskabet og de indre grænser. Om diskursanalysens bidrag til forskningen i interkulturelle forhandlinger. In: Fagsprogsforskningen i Danmark. Netvark LSP SSP. Nyhedsbrev Nr. 4, 1-11.

Danterm Project Group (1979): Danterm - The Danish Terminological Data Bank. In: Cebal. Special Issue on Terminology. København, 132-157.

Duvå, Grete/Laursen, Anna-Lise/Maidahl, Lisbeth: Brugerundersøgelse vedrørende oversættelse af fagtekst. In: Nordiske studier i leksikografi. Rapport fra Konferanse om leksikografi i Norden 28.-31. mai 1991. Red. av Ruth Vatvedt Fjeld. Oslo, 244259.

Dyrberg, G./Faber, D./Hansen, S.L./Tournay, J. (1988): Etablering af et juridisk tekstkorpus. In: Hermes 1, 209-227.

Dyrberg, G./Faber, D./Hansen, S.L./Tournay, J. (1991): Oprettelse af fagsproglige tekstkorpora. Engelsk-fransk-dansk juridisk sprog. Aftaleret. København (ARK 60).

Engberg, Jan (1992): Signalfunktion und Kodierungsgrad von sprachlichen Merkmalen in Gerichtsurteilen. In: Hermes. 65-82. (= 1992a).

Engberg, Jan (1992): Wie analysiert man Gerichtsurteile? - Ein Plädoyer für eine textsortenspezifische Textanalyse. In: Anette Grindsted/Johannes Wagner (eds.): Communication for Specific Purposes/Fachsprachliche Kommunikation. Tübingen 93-111. (Kommunikation und Institution 21). (= 1992b).

Engel, Gert (april 1979): Teser om forholdet mellem terminologi og leksikologi (foredrag i København, citeret efter Frandsen 1979b, 4-5). (= 1979a).

Engel, Gert (1979): Organisation, Arbeitsformen und Resultate dänischer Terminologiearbeit seit 1974. In: Cebal 5, København 18-27. (= 1979b).

Engel, Gert (red.): Proceedings af seminar om korpuslingvistik i fagsprogsforskningen. [Kolding] [1993].

Engel, Gert/Madsen, Bodil Nistrup (1985): DANTERM. In: TermNet News 12, 8-10.

Eyben, W.E. von (1989): Juridisk stil og sprogbrug. In: W.E. von Eyben (red.): Juridisk Grundbog, Bd. 3. København, 11-62.

Faber, Dorrit (1983): Kollokationer og oversættelse. In: Hanne Martinet/Viggo Hjørnager Pedersen/Jacques Quistgaard: AScLA-Symposiet. Oversættelse og tolkning. 4.- 
5. oktober 1982. Foredrag holdt ved AScLA-Symposiet Oversættelse og tolkning 4.-6. oktober 1982 på Københavns Universitet. København 157-168.

Fagsproglig forskningsprofil 1987 = Indlæg fra Forskningsseminaret: "Fagsproglig forskningsprofil”. Kolle-Kolle 22. maj 1987. København (= ARK 39).

Firth, Alan (1991): Discourse at work: negotiation by telex, fax and phone. Aalborg .

Frandsen, Finn (1990): Men kan man overhovedet forske og undervise i almensprog? In: Fagsprogsforskningen i Danmark. Netvark LSP, SSP. Nyhedsbrev 1, 12-15.

Frandsen, Lene (1979): Eine terminologische Behandlung des thermostatischen Heizkörperventils - mit dem Hauptgewicht auf die Bestandteile des thermostatischen Heizkörperventils. In: Cebal 5, 83-115. (= 1979a).

Frandsen, Lene (1979): Terminologi og Leksikologi. Forskelle og Ligheder. København (ARK 2) ( =1979b).

Frandsen, Lene (1982): Definition. Objekter, metoder og regler med terminologisk inventar for ventilation og luftkonditionering. København (ARK 15).

Grinsted, Annelise (1991): Terminologi som en del af en helhedsløsning. In: Fagsprogsforskningen i Danmark. Netvark LSP, SSP. Nyhedsbrev 3, 1-14.

Grinsted, Annelise/Toft, Bertha (1994): Leksikografi og terminologi. In: Hjørnager Pedersen/Krogh-Hansen 61-75.

Grøn, Hanne (1988): Anmeldelse af Peter Harms Larsen: Ned med fagsproget. In: Hermes 1, 245-250.

Gubba, Wilhelm (1993): Juridisk Ordbog dansk-tysk. København.

Hamburger, Arne (1982): Lidt om breve til modparten. In: Københavns Retshjalp. 97. Årsberetning. København, 13-15.

Hamburger, Arne (1988): Officiel sprogbrug. In: Sproget her og nu. København, 146156. (Dansk Sprognævns Skrifter 14).

Hansen, Erik (1986): Ping- og pampersprog. København.

Hansen, Inge Gorm (1978): Pragmatiske aspekter af lovtekster eksemplificeret ved uddrag af den danske og den engelske ægteskabslov. In: Kommunikativ kompetens och fackspråk, 339-354.

Hansen, Inge Gorm/Lundquist, Lita/Rasmussen, Jens (1978): Analyse af lovtekster. In: Kommunikativ kompetens og fackspråk, 333-338.

Harboe, Eva/Poulsen, Sven Olaf (1983): Hovedtendenser vedrørende tempus- og modusbrugen i danske og tyske domme i 1. instans. København (= ARK 17).

Hare Hansen, Jens (1992): Fagsproglig kommunikation i tekniske brochurer. En undersøgelse af udvalgt informationsmateriale fra landbrugsmaskinesektoren. Aalborg (Institut for sprog og interkulturelle kulturstudier. Arbejdspapirer 19).

Hauschildt, Bent (1989): Terminologi. In: Hermes 3, 99-124.

Henriksen, Carol (1991): Dansk i EF og EF-dansk. In: 3. mфde om Udforskningen af Dansk Sprog. Aarhus: Århus Universitet, 144-157. 
Henriksen, Torben (1992): Spansk-dansk juridisk ordbog. København.

Hjort-Pedersen, Mette (1994c): Translating the Illocutionary Force of a Danish Will: A Felicitous Approach. In: Jakobsen, 129-142.

Hjørnager Pedersen, Viggo/Krogh-Hansen, Niels (1994): Oversattelseshåndbogen. København: Munksgaard.

Hoffmann, Lothar (1988): Vom Fachwort zum Fachtext. Beiträge zur Angewandten Linguistik. Tübingen: Narr (Forum für Fachsprachenforschung, 5).

Høedt et. al. 1982 = Jørgen Høedt/Lita Lundquist/Heribert Picht/Jacques Qvistgaard: Proceedings of the 3rd European Symposium on LSP. København, August 1981 "Pragmatics and LSP”. København 1982.

Jakobsen, Arnt Lykke (1992): A Survey of European Approaches to LSP, 1970-1990: An Outline of OFT Project 1. In: ARK 65, 25-33. (= 1992a).

Jakobsen, Arnt Lykke: Oversættelse af komposita i fagsproglige tekster (Eng-da/daeng). In: Hermes 8, 29-42. (= 1992b).

Jakobsen, Arnt Lykke (1994): Translation - a Productive Skill. In: Bergenholtz et al., 41-70. (=1994a).

Jakobsen, Arnt Lykke: Towards a Definition of Translation Types. In: Jakobsen 1994c, 33-56. (= 1994b)

Jakobsen, Arnt Lykke (ed.) (1994): Translating LSP Texts: Some Theoretical Considerations. København (Copenhagen Studies in Language 16). (= 1994c)

Justitsministeriet 1969 = Justitsministeriet: Vejledning om sproget i love og andre retsforskrifter. København 1969.

Karker, Allan (1980): EF-dansk. In: Ord til andet. Iagttagelser og synspunkter 2. København , 35-46. (Dansk Sprognævns skrifter 10).

Karker, Allan (1982): Ti år efter - eller - Lovsprogets forandring. In: Festskrift til Professor, dr. jur. W.E. von Eyben. København, 191-207.

Karker, Allan (1993): Dansk i EF - en situationsrapport om sproget. København: Gad. (Nordisk Sprogsekretariats Skrifter, 16).

Kaufmann, Uwe/Bergenholtz, Henning (1992): Genteknologisk ordbog. Dansk-engelsk/engelsk-dansk molekylarbiologi og DNA-teknologi. København: Gad.

Kaufmann, Uwe (1993): Anvendelse af det danske genteknologiske tekstkorpus ved udarbejdelsen af Genteknologisk ordbog, med specielt henblik på udvælgelsen af eksempler. In: Engel, 56-68.

Kewley-Draskau, Jennifer (1994): Om oversættelse af fagsprog. In: Hjørnager Pedersen/Krogh-Hansen, 97-108.

Kjær, Anne Lise: Normbetingede ordforbindelser i tysk sprog. København 1990 (ARK 56).

Kommunikativ kompetens och fackspråk $1978=$ Kommunikativ kompetens och fackspråk. Föredrag hållna vid ett symposium om Språket i bruk i Södertälje 6. - 8. oktober 1978 och utgivna av Svenska föreningen för tillämpad språkvetenskap (ASLA). Lund. 
Kristensen, Bente (1985): National Organisation/Co-operation. In: TermNet News. Special Issue on the Nordic Countries 12, 4.

Krogh-Hansen, Niels (1994): Om oversættelse af fagsproglige tekster. In: Hjørnager Pedersen/Krogh-Hansen, 109-126.

Kromann, Hans-Peder (1988): Hvad er erhverssproglig forskning? In: Hermes 1, 189196.

Kromann, Hans-Peder (1989): Opgaver og problemstillinger for dansk fagsprogsforskning. In: Hermes 2, 127-132.

Kromann, Hans-Peder (1991): Base b11: FAgSPROGSBIBLIOGRAFIEN. In: Hermes 7, 103108.

Kromann, Hans-Peder (1995): Information Base for Specialised Language. København: Biblioteket på Handelshøjskolen i København.

Kromann, Hans-Peder/Mikkelsen, Hans Kristian (1988): Fagsproglig kommunikation. En selektiv systematisk bibliografi ca. 1980-88. København (Ark 45).

Kromann, Hans-Peder/Thomsen, Knud Troels: Akzente der Fachsprachenforschung von heute und morgen. Bericht vom Kopenhagener Werkstattgespräch 1.-2. Juni 1988. In: Terminologie et traduction 1989, 137-160.

Larsen, Karl (1895): Dansk Soldatersprog. Til Lands og til Vands. København.

Larsen, Peter Harms (1987): Ned med fagsproget! - om fagsprog som kommunikationsmodstand. In: Fagsproglig forskningsprofil, 1-30. (= 1987a)

Larsen, Peter Harms (1987): Skriv Sundere. En kritisk brugsbog for sygeplejersker om skriftlig kommunikation. København. (=1987b).

Lauridsen, Karen Margrethe (1992): The Meaning and Use of the Modals CAN and MAY in English Contract Law Texts. In: Hermes 9, 43-64.

Lauridsen, Ole/Riiber, Theis/Søndergaard, Henning (1991): Erstellung eines dänischen und eines deutschen Textkorpus - Fachsprache der Gentechnik. In: Hermes 6, 125137.

List, Pia/Wagner, Johannes: Nationale Stereotype im internationalen beruflichen Alltag: Überlegungen anhand eines Fallbeispiels. In: Anette Grindsted/Johannes Wagner (eds.): Communication for Specific Purposes/ Fachsprachliche Kommunikation. Tübingen 1992, 210-226. (Kommunikation und Institution 21)

Lundquist, Lita (1978): Teksttypebestemmelse af en lovtekst via en semantisk dybdestruktur. In: Kommunikativ kompetens och fackspråk, 355-372.

Madsen, Dorte (1994): Et handlingsteoretisk grundlag for faglig oversættelse. In: Hjørnager Pedersen/Krogh-Hansen, 131-138.

Maidahl, Lisbeth (1992): Brugen af fagordbøger. En empirisk undersøgelse. In: ARK 65, , 205-218.

Maidahl Christiansen, Lisbeth/Duvå, Grete/Laursen, Anna-Lise (1994): Das Translationswörterbuch für Fachsprachen. Ein integriertes Konzept. In: Schaeder/ Bergenholtz, 269-282. 


\section{4}

Mikkelsen, Hans Kristian (1989): Two new Bibliographies about Special Language Research. In: Hermes 2, 133-135.

Mikkelsen, Hans Kristian (1990): Fagsprog og almensprog: særsprog og fællessprog. In: Fagsprogsforskningen i Danmark. Netvaerk LSP SSP. Nyhedsbrev Nr. 1, 1-6.

Mikkelsen, Hans Kristian/Kromann, Hans-Peder (1988): Fagsprog og fagsproglig kommunikation ca. 1970-1988. En udførlig systematisk bibliografi på database. København.

Mourier, Lise (1987): Den erhvervssproglige forsknings vilkår og problemer. In: Fagsproglig Forskningsprofil, 1-8.

Munck, Lena: Introduktion til dansk teknisk sprogbrug. In: Hjørnager Pedersen/KroghHansen 1994, 139-172.

Møller, Bernt (1992): Oversættelse af teknisk tekst: Anførte problemer og konstaterede fejl. In: ARK 65, 219-244.

Møller, Bernt: User-friedly LSP dictionary outside matter. In: Schaeder/Bergenholtz 1994, 325-348.

Nielsen, Sandro (1994): The Bilingual LSP Dictionary. Principles and Practice for Legal Language. Tübingen: Narr.

Nistrup Madsen, Bodil (1985): Danterm - dansk termbank. In: Nordisk terminologikursus, 455-463.

Nordborg Nielsen, Joel (1992): Teksttype og sprogbrug. Træk af sprogbrugen i betjeningsvejledninger i russisk. In: $A R K$ 65, 55-86.

Nordborg Nielsen, Joel: LSP-Grammar. Some Reflections on the Relation between Professional Language and Elements of its Grammar. In: Jakobsen 1994c, 57-87. (= 1994a)

Nordborg Nielsen, Joel: Professions, Specific Purpose Languages, and Professional Texts. Elements of the Professional Translator's Knowledge. In: Bergenholtz et al. 1994, 15-39. (= 1994b)

Nordborg Nielsen, Joel (1994): Der er en verden uden for sproget. Om at sikre kvalitet i oversættelse af fagsproglige tekster. In: Hermes 12, 91-108. (= 1994c)

Nordisk terminologikursus $1985=$ Nordisk terminologikursus 2. "Rolighed". Skodsborg, DK. 5.-6. august 1985. Bind 1-2. København.

Normann Jørgensen, Jens (1984): Er selskabet pligtig uopholdelig at meddele sikrede nedennævnte eller skal vi fortælle Dem det straks? In: Mål og male 1, 24-29.

Pedersen, Jette (1993): Engelsk og dansk pumpeteknologisk korpus. In: Engel, 46-51.

Pedersen, Jette: Fagsystematik. In: Bergenholtz/Tarp 1994a, 84-90. (= 1994a).

Pedersen, Jette (1994): Anskueliggørelse af faglige relationer i brancheordbøger. In: LexicoNordica 1, 203-228. (= 1994b).

Picht, Heribert (1979): Der Terminologieunterricht an der Handelshochschule in Kopenhagen. In: CEBAL 5, 28-82. 
Picht, Heribert: Hvad gør et almentsproget verbum til et fagsprogligt verbum? Verbernes terminologisering. In: AScLA-Symposiet 1983, 191-201.

Picht, Heribert (1985): Terminology Research and Terminology Training. In: Term Net News. Special Issue on the Nordic Countries 12, 5-6. (= 1985a)

Picht, Heribert (1985): Begrebet som et centralt element i terminologilæren. In: Nordisk terminologikursus, 45-69. (= 1985b)

Picht, Heribert (1985): Begrebsrelationer og begrebssystemer. In: Nordisk terminologikursus, 117-167. (= 1985c)

Picht, Heribert (1985): Leksikografi - Terminografi. In: Nordisk terminologikursus, 351-372. $(=1985 \mathrm{~d})$

Picht, Heribert (1985): Termer og deres fagsproglige omgivelser -fagsproglig fraseologi. In: Nordisk terminologikursus, 296-336. (= 1985e)

Picht, Heribert (1985): Discipliner og fagområder. In: Nordisk terminologikursus, 3544. $(=1985 f)$

Picht, Heribert (1985): Uddannelse af terminologer - State of the art. In: Nordisk terminologikursus, 679-693. (= 1985g)

Picht, Heribert (1988): Fachsprachliche Phraseologie - Die Terminologische Funktion von Verben. In: Terminologie et traduction 3, 65-78.

Picht, Heribert: Grænseflader mellem terminologi og vidensteknik. In: Toft 1993a, 2132. (= 1993a)

Picht, Heribert: Vidensrepræsentation i termbanker og vidensbanker. In: Toft 1993a, 54-76. (= 1993b)

Picht, Heribert: Terminologiens opståen, dens grundlæggende elementer og dens forbindelse til andre discipliner og vidensområder. In: Fagspråk i Norden. Rapport fra en konference i Lund 4.-6. desember 1992. Oslo, 29-49. (= 1993c)

Rasmussen, Jens (1978): Nogle syntaktiske karakteristika for lovtekster. In: Kommunikativ kompetens och fackspråk, 373-384.

Riis, Povl (1981): Lægeligt og lægevidenskabeligt sprog. In: Sproget i Industrisamfundet. Hårby, 22-28. (Modersmål-Selskabets Årbog 1981)

Schack, Jørgen (1990): Hvad siger loven? In: Hermes 5, 113-121.

Schaeder, Burkhard: Maschinenlesbare Textkorpora des Deutschen und des Englischen. Eine Dokumentation. In: Henning Bergenholtz/Burkhard Schaeder (Hrsg.): Empirische Textwissenschaft. Aufbau und Auswertung von Text-Corpora. Königstein/Ts. 1979, 325-336.

Schaeder, Burkhard/Bergenholtz, Henning (Hrsg.) (1994): Das Fachwörterbuch. Fachwissen und seine Repräsentation in Wörterbüchern. Tübingen: Narr.

Spang-Hanssen, Henning (1979): Traits and trends of terminological work in Denmark. In: Cebal. Special Issue on Terminology. København, 9-17.

Spang-Hanssen, Henning (1983): Fagsprog og almensprog. In: Skrifter om anvendt og matematisk lingvistik 10, 85-100. 
Spang-Hanssen, Henning (1984): Navn og gavn - synspunkter på BDI-terminologi. In: Fremtid og information. Dansk Teknisk Litteraturselskabs Jubilæumsbog. Lyngby, 219-234. (Dansk Teknisk Litteraturselskab skriftserie nr. 55)

Spleth, P. (1987): Et fors $\emptyset$ gå forkortelse af domsskrivning. In: Ugeskrift for retsvasen 2, 16-19.

Språk i Norden/Sprog i Norden 1983 = E.Bojsen/M.Reuter/S.Løland/C.Grünbaum: Språk i Norden/Sprog i Norden 1983. Årsskrift for Nordisk språksekretariat og språknemndene i Norden. Oslo. Stockholm. København.

Stumman, Bjarne: Anvendelsesmuligheder og fagligt indhold af det danske genteknologiske tekskorpus. In: Engel 1993, 69-74.

Svendsen, Lisbet Pals (1987): Erhvervssproglig forskning set i relation til erhvervslivet - hvem bestemmer egentlig, hvad der skal forskes i? In: Fagsproglig forskningsprofil, 1-11.

Sørensen, Henrik Selsøe (1983): FAGSPROG - et forsøg på en pragmatisk-kommunikativ karakteristik. In: Nordisk Tidsskrift for fagsprog og terminologi 2, 2-5.

Sørensen, Henrik Selsøe (1992): Oversætterens viden som parameter ved oversættelse af faglige tekster. In: ARK 65, 133-158.

Sørensen, Henrik Selsøe: Knowledge and LSP Translation. When does a translator have to be unfaithful? Some cases of LSP translation. In: Jakobsen 1994c, 7-27.

Tarp, Sven: Fagordbøgers funktion. In: Bergenholtz/Tarp 1994, 16-24. (= 1994a)

Tarp, Sven: Faglig indledning. In: Bergenholtz/Tarp 1994, 160-165. (= 1994b)

Thomsen, K.T. (1993): Orddannelse og oversættelse. In: M.Herslund/H.Wegener (red.): Oversættelse. København, 103-114. (ARK 67)

Toft, Berta (udg.) (1993): Terminologi, EDB \& Vidensteknik. Kolding. (= 1993a).

Toft, Berta: Begrebsrelationer i terminologi og vidensteknik. In: Toft 1993a, 103-124. $(=1993 \mathrm{~b})$

Villemoes, Anette (1983): En oversættelsesstrategi dansk - spansk for verbalhelheder i teknisk sprog. København (ARK 19). 
